\title{
CENTER LEARNING MODEL IN CHILDREN AGED 4-5 YEARS
}

\author{
Tri Ulya Wardati Qori'ah'), Ruli Hafidah'), Nurul Kusuma Dewi ${ }^{3)}$ \\ Program Studi PG-PAUD, Universitas Sebelas Maret \\ threulya@gmail.com
}

\begin{abstract}
This study aimed to describe the application of the beyond centers and circle time in children aged 4-5 years at Surakarta Islamic Consecrated Kindergarten. This problem was examined with a qualitative approach and the type of research case study. The research subjects involved were children, teachers, and parents. Data collected by researchers through interviews, observation and documentation. The data analysis technique used the Miles and Huberman analysis model. The technique of data validity testing was by source and technique triangulation. The results research of the application of the central learning model was carried out by organizing learning focusing on children in a circle using four types of scaffolding, namely playing environment, before playing, during play, and after playing. Bakti IX Islamic Kindergarten applied five school days, as well as one type of center every day, there are five centers that are implemented namely beam centers, centers of life skills, arts centers, preparation centers, and role-playing centers. The application of beyond centers and circle time can stimulate children to be able to optimize the six developmental fields of children. Learning media used ware APE and also the use of used goods.
\end{abstract}

Keywords: Beyond centers and circle time, childrean aged 4-5 years

\section{MODEL PEMBELAJARAN SENTRA PADA ANAK USIA 4-5 TAHUN}

\begin{abstract}
Abstrak: Penelitian ini bertujuan untuk mendeskripsikan penerapan model pembelajaran Sentra pada anak usia 4-5 tahun di TK Islam Bakti IX Surakarta. Permasalahan ini diteliti dengan pendekatan kualitatif dan jenis penelitiannya studi kasus. Subyek penelitian yang terlibat adalah anak, guru, dan orangtua. Data yang dikumpulkan oleh peneliti melalui wawancara, observasi dan dokumentasi. Teknik analisis data menggunakan model analisis Miles and Huberman. Teknik uji validitas data dengan perpanjangan pengamatan,ketekunan pengamatan, triangulasi sumber dan triangulasi tenik. Hasil penelitian penerapan model pembelajaran sentra dilakukan dengan penyelenggaraan pembelajaran berfokus pada anak dalam lingkaran menggunakan empat jenis pijakan yaitu pijakan lingkungan main, pijakan sebelum main, pijakan selama main, dan pijakan setelah main. TK Islam Bakti IX menerapkan lima hari sekolah, serta satu jenis sentra setiap harinya, terdapat lima sentra yang diterapkan yaitu sentra balok, sentra keterampilan hidup, sentra seni, sentra persiapan, dan sentra bermain peran. Penerapan model pembelajaran sentra dapat menstimulus anak untuk dapat mengoptimalkan enam bidang perkembangana anak. Media pembelajaran yang digunakan yaitu APE dan juga pemanfaatan barang bekas.
\end{abstract}

Kata Kunci: Model pembelajaran sentra, anak usia 4-5 tahun

\section{PENDAHULUAN}

Pendidikan anak usia dini menurut Suyadi (2014) [1] yaitu pendidikan yang diselenggarakan dengan tujuan untuk menfasilitasi pertumbuhan dan perkembangan anak secara menyeluruh atau menekankan pada pengembangan seluruh aspek kepribadian anak. Pemberian pelayanan pada anak diharapkan dapat mengoptimalkan perkembangan anak. Salah satu model yang diterapkan di Indonesia adalah model pembelajaran sentra. Aziz (2017) [2] menjelaskan bahwa model pembelajaran sentra berdasarkan pada asumsi bahwa anak belajar melalui bermain dengan benda-benda dan 
orang-orang di sekitarnya (lingkungan).

Model pembelajaran sentra berasal

dari Creative Center For Childhood Research And Training (CCCRT) di Florida, Amerika Serikat, penemu dan pengembangnya adalah Dr. Pamela Phelps. Model pembelajaran ini diadaptasi pertama kali oleh drg. Wismiarti yang bercita-cita untuk dapat mewujudkan anak yang cerdas spiritual tanpa mengabaikan kecerdasan yang lainnya (Hanafi, 2014) [3]. Kemudian baru secara resmi tahun 2004 kerjasama antara Direktorat PAUD, Dirjen, PLSP, Depdiknas, dan Creative Center for Childhood Research and Training (CCCRT) dan dilakukan penyebaran model pembelajaran sentra ke seluruh Indonesia (Oktaria, 2014) [4]. Di indonesia model pembelajaran BCCT ini lebih dikenal dengan sebutan model pembelajaran sentra.

Proses pembelajaran sentra meliputi penataan lingkungan main, penyambutan anak, main pembukaan, transisi, kegiatan inti dimasing-masing kelompok yang meliputi pijakan sebelum main, pijakan selama main, pijakan setelah main, makan bekal bersama, dan kegiatan penutup (Depdiknas, 2006) [5]. Latif et al (2013) [6] menjelaskan bahwa guru mengelola bahan dan alat main yang cukup (tiga tempat main untuk tiap anak) memenuhi tiga jenis main (main sensorimotor, main peran, dan main pembangunan) merencanakan densitas dan intensitas main serta mendukung pengalaman keaksaraan anak. Setidaknya ada 6 jenis sentra yang umunya di terapkan di PAUD yaitu sentra imtak, sentra bahan alam, sentra seni dan kreativitas, sentra bermain peran, sentra balok, dan sentra persiapan (Suyadi \& Dahlia, 2014) [7].

Claesses \& Garrett (2014) [8] berpendapat bahwa pentingnya pemahaman dalam sesbuah program yang diterapkan di TK karena akan berpengaruh pada prestasi belajar anak. Hasil penelitian penerapan model https://jurnal.uns.ac.id/ecedj

pembelajaran

sentra dapat meningkatkan minat dan aktivitas anak dalam belajar (Lestari, Marhaeni \& Suastra, 2013) [9], meningkatkan kecerdasan verbal linguistik anak (Masrurah, 2014) [10], mengembangkan kecerdasan majemuk pada anak (Latif et al, 2013) [6].

Penerapan pembelajaran sentra di PAUD harus disesuaikan dengan karakterisik perkembangan anak usia dini. Perkembangan pada anak usia dini menurut Hurlock (2013) [11] dasar awal cenderung bertahan dan mempengaruhi sikap dari perilaku anak sepanjang hidupnya, yang meliputi berbagai aspek yaitu perkembangan fisik, motorik, sosialemosional, moral keagamaan, dan perkembangan kognitif. Perkembangan moral menurut Wiyani (2014) [12] perubahan psikis pada anak usia dini yang memungkinkannya dapat mengetahui mana perilaku yang baik yang dapat dilakukan dan perilaku buruk yang harus dihindari berdasarkan norma tertentu. Allen \& Martoz (2010) [13] menjelaskan bahwa perkembangan fisik motorik anak akan bertambah sesuai dengan bertambahnya usia, kemampuan melakukan gerakan semakin gesit dan tangkas. Beaty (2013) [14] menjelaskan bahwa kemampuan kognitif anak mulai berkembang untuk mengelompokkan dengan benar dan kemampuan mengingat dan berkembangnya kemampuan berpikir anak.

Perkembangan bahasa pada anak usia dini menurut Wiyani (2014) [12] perubahan sistem lambang bunyi yang berpengaruh terhadap kemampuan berbicara anak usia dini. Anak usia dini mulai mengembangkan diri untuk dapat bermain bersama dan memiliki teman (Hurlock, 2013) [11]. Kemampuan seni anak dapat berkembang bersama 
dengan perkembangan yang lainnya, aktivitas bernyanyi menggambar dan mewarnai dapat mengoptimalkan perkembangan anak.

TK Islam Bakti IX yang berdiri sejak tahun 1970. TK ini menerapkan model pembelajaran sentra terdiri dari sentra balok, sentra keterampilan hidup, sentra seni, sentra persiapan, dan sentra main peran untuk lima hari sekolah, sehingga satu jenis sentra dalam satu hari. TK menggunakan lembar kerja yang dibuat sendiri oleh guru dan guru memanfaatkan barang bekas sebagai media dan sumber belajar anak. Berbagai data mendukung temuan peneliti di lapangan, hampir sebagian besar anak yang berusia 4-5 tahun (kelompok A) di sekolah tersebut selalu bertanggung jawab mengembalikan sesuatu sesuai dengan tempatnya, memiliki sikap taat pada aturan dan waktu yang telah di sepakati, memiliki kemandirian dalam memilih kegiatan dan menyelesaikan tugas sampai selesai. Sehingga di peroleh tujuan penelitian untuk mengetahui penerapan model pembelajaran sentra pada anak usia 4-5 tahun di TK Islam Bakti IX Surakarta.

\section{METODE PENELITIAN}

Penelitian dilaksanakan di TK Islam Bakti IX Surakarta sebagai satusatunya TK yang menerapkan model pembelajaran sentra di gugus dua Kecamatan Laweyan Surakata. Penelitian ini dilakukan di Kelompok A. Waktu penelitian dilakukan sejak bulan Maret sampai dengan bulan November 2018. Penelitian dilaksanakan dengan menggunakan pendekatan kualitatif dan jenis penelitian studi kasus. Data yang terkumpul berupa data kualitatif tentang informasi pelaksanaan model pembelajaran sentra di TK Islam Bakti IX Surakarta. Sumber data yaitu menggunakan sumber data primer berupa dan sumber data sekunder.

Teknik pengumpulan data yang digunakan adalah Observasi,
Wawancara dan Dokumentasi. Observasi dengan melakukan pengamatan berperan dan tidak berperan. Wawancara yang digunakan adalah semitersetruktur. Dokumentasi dilakukan untuk mendukung data yang relevan dengan bahan penelitian. Uji validitas data yang digunakan adalah ketekunan pengamatan, perpanjangan pengamatan, triangulasi sumber dan triangulasi teknik. Teknik analisis data menggunakan menggunakan model analisis interaksi Miles and Huberman. Teknik analisis ini dilakukan terus-menerus sehingga data mencapai kejenuhan. Kejenuhan data dapat diukur dengan tidak diperolehnya lagi data dan informasi baru. Prosesnya meliputi pengumpulan data, penyajian data, penerikan kesimpulan dan verifikasi data.

Pengumpulan data dilakukan melalui dokumentasi, wawancara dan observasi. Data yang terkumpul di klasifikasikan dan direduksi. Penyajian data dilakukan dalam bentuk koding. Sebagaimana tabel di bawah ini:

\begin{tabular}{|c|c|c|c|c|c|c|c|c|}
\hline Topik & Kode & Wawancara & dokumentasi & observasi & $\begin{array}{l}\text { Kepala } \\
\text { sekolah }\end{array}$ & Guru & $\begin{array}{l}\text { Orang } \\
\text { tua }\end{array}$ & Anak \\
\hline Daskripsi Lembaga & $\mathrm{DL}$ & $\mathrm{CW}$ & CD & - & KS & G & & \\
\hline $\begin{array}{l}\text { Kurikulum } \\
\text { Pemblajasan }\end{array}$ & PM & $\mathrm{CW}$ & CD & $\dot{\mathrm{CL}}$ & $\begin{array}{l}\mathrm{KS} \\
\mathrm{KS}\end{array}$ & $G$ & OT & AN \\
\hline a. Perencanaan & PRC & $\mathrm{cW}$ & $C D$ & CI & $\mathrm{KS}$ & G & . & \\
\hline b. Pelaksanaan & PLK & $\mathrm{cW}$ & CD & CI & $\mathrm{KS}$ & G & - & \\
\hline 1) Sentra & $\mathrm{SP}$ & $\mathrm{cw}$ & $C D$ & $\mathrm{CL}$ & Ks & G & . & $\cdot$ \\
\hline $\begin{array}{l}\text { restispan } \\
\text { 2entra Balok }\end{array}$ & SB & $\mathrm{cW}$ & $C D$ & $\mathrm{CL}$ & ks & G & . & - \\
\hline $\begin{array}{l}\text { 3) Sentra } \\
\text { Ketergmpilan }\end{array}$ & SKH & $\mathrm{CW}$ & $C D$ & $\mathrm{CI}$ & KS & G & $\therefore$ & - \\
\hline $\begin{array}{l}\text { Keterampilan } \\
\text { Hidup }\end{array}$ & & & & & & & & \\
\hline 4) Sentra Seni & SS & $\mathrm{CW}$ & CD & CL & KS & G & - & - \\
\hline $\begin{array}{l}\text { 5) Sentra Bermain } \\
\text { Peran }\end{array}$ & SBP & $\mathrm{CW}$ & $C D$ & $\mathrm{CL}$ & KS & G & - & - \\
\hline c. Evaluasi & EVL & $\mathrm{CW}$ & $C D$ & CL & KS & G & - & - \\
\hline Fasilitas & FSL & & $C D$ & CL & KS & & & \\
\hline Penatann Linglkungan & PLG & $\mathrm{CW}$ & CD & $\mathrm{CL}$ & & G & - & \\
\hline Perkembangan Anak & $\mathrm{PA}$ & $\mathrm{CW}$ & $C D$ & CL & KS & G & - & AN \\
\hline a. Nam & NAM & $\mathrm{CW}$ & CD & CL & - & G & - & AN \\
\hline $\begin{array}{l}\text { b. Fisisik Motorik } \\
\text { c. Bahasa }\end{array}$ & $\begin{array}{l}\text { FMM } \\
\text { BHS }\end{array}$ & $\begin{array}{c}\mathrm{CW} \\
\mathrm{CW}\end{array}$ & $\begin{array}{l}C D \\
C D\end{array}$ & $\begin{array}{cl}\mathrm{CI} \\
\mathrm{CI}\end{array}$ & : & ${ }_{G}^{G}$ & : & ${ }_{\mathrm{AN}}^{\mathrm{AN}}$ \\
\hline d. Kognitif & KOG & $\mathrm{cW}$ & $C D$ & $\mathrm{CL}$ & . & G & . & $\mathrm{AN}$ \\
\hline e. Sosial Emosional & SE & $\mathrm{CW}$ & $C D$ & $\mathrm{CL}$ & - & G & - & $\mathrm{AN}$ \\
\hline f. Seni & $\mathrm{SNI}$ & $\mathrm{CW}$ & $C D$ & $\mathrm{CL}$ & - & G & 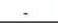 & AN \\
\hline
\end{tabular}

\section{HASIL DAN PEMBAHASAN Hasil Penelitian}

Berdasarkan hasil penelitian maka didapatkan data. Pembahasan penerapan model pembelajaran sentra di TK Islam Bakti IX Surakarta sesuai dengan hasil penelitian ini dapat di bahas sebagai berikut:

\section{Perencanaan Pembelajaran}


Penerapan model pembelajaran sentra disajikan dalam bentuk perencanaan program. Perencanaan kegiatan pembelajara dibuat dalam rencanan program semester yang memuat perencanan kegiatan mingguan (RPPM), dalam perencanaan mingguan terdapat jenis kegiatan yang disesuaikan dengan jenis sentra dan akan di aplikasikan lebih detail dalam rencana program harian (RPPH).

Perencanaan pembelajaram dibuat berdasarkan hasil diskusi bersama semua guru dan kepala sekolah atau usulan kegiatan dari guru sentra kemudian di sampaikan kepada guru kelas. Tema dipilih dengan mempertimbangkan kedekatan dengan anak, mudah, menarik, pemanfaatan lingkungan sekitar anak, insidental. TK menginternalisasikan nilai islam dalam setiap tema yang dipilih, seperti tema aku dan keluargaku dikembangkan menjadi aku dan keluarga muslim.

Pelaksanaan Harian (RPPH) dibuat oleh guru sentra sesuai dengan jenis sentra yang akan di lakukan. Puncak tema bertujuan untuk mengetahui secara langsung gambaran materi pembelajaran yang sedang di pahami. Puncak tema dilakukan setidaknya satu bulan sekali. Kegiatannya dengan melakukan kerjasama dengan orang tua, jenis kegiatan dapat dilakukan di sekolah maupun di luar sekolah seperti membuat kue atau makanan, makan bersama, pameran hasil karya, pertunjukan, panen tanaman, dan kunjungan.

\section{Pelaksanaan Pembelajaran}

Berdasarkan hasil observasi,
diperoleh data bahwa kegiatan
pembelajaran di TK Islam Bakti IX Surakarta sedikit berbeda dengan penerapan di TK yang lainnya. Kegiatan pembelajaran berlangsung dari jam 7.3011.30 WIB dalam lima hari sekolah. Kegiatan pembelajaran dalam satu hari menerapkan satu jenis sentra yang di atur dalam bentuk jadwal harian, namun kadang bisa berubah sesuai dengan kesiapan alat dan juga bahan yang tersedia dan kesepakatan dengan guru sentra. Selain itu TK memiliki SOP (Standar operasional prosedur) dalam pelaksanaan kegiatan keseharian, yang meliputi SOP Penyambutan, penataan lingkugan main, kegiatan bekajar mengajar, buang air kesil atau besar, makan bekal, kegiatan cuci tangan, kegiatan sikat gigi, kegiatan pembukaan, dan kegiatan akhir.

Proses pembelajaran sentra di TK Islam Bakti IX sedikit berbeda dengan pelaksanaan pada TK yang lainnya. penyambutan dilakukan di depan sekolah, kemudian sebagian guru melakukan penataan lingkungan main untuk mempersiapkan alat dan bahan yang akan di gunakan. Setelah anak meletakkan sepatu dan tas di rak yang telah tersedia maka guru mempersilahkan anak untuk melakukan aktifitas literasi seperti menulis, menggambar bebas, membaca iqro' atau bermain bebas bersama teman. Anak dipersilahkan untu melakukan aktifitasnya sendiri atau meminta di bimbing oleh guru, bahkan orang tua juga ada yang berpartisipasi. Tepat jam 08.00 guru mempersilahkan anak untuk melakukan aktivitas pembiaaan NAM (nilai agama moral) yang meliputi sholat dhuha, hafalan dan berdoa.

Kegiatan wudhu dilakukan tepat pukul 08.00 WIB. Guru memulai kegiatan sholat dhuha dengan bercakap, kemudian guru membimbing sholat dhuha bagi kelas A. Setelah itu guru mengajak anak berdzikir bersama dan anak melipat sendiri mukena dan sajadah lalu mengembalikan ke rak yang tersedia.

Anak-anak duduk melingkar bersama guru. lalu mempersilahkan anak untuk merapikan diri, memakai jilbab bagi yang perempuan. Guru mengajak anak untuk menyanyi, berdoa, membaca surat pendek, dan bersyahadat. Guru memimpin 
kegiatan fisik motorik sejak pemanasan sampai pendinginan. Kegiatan fisik motorik bisa di lakukan mandiri di dalam kelas masing-masing atau bersama kelompok $\mathrm{B}$ di halaman sekolah. Setelah beristirahat sebentar, guru mengajak anak untuk makan bersama.

Tepat jam 09.00 WIB anak mencuci tangan, mengambil bekal, berdoa, bercakap bersama tentang bekal yang dibawa, guru juga menjelaskan makanan yang sebaiknya di bawa, setelah makan selesai anak akan merapikan tempat makan dan membuang sampah lalu bercuci tangan dan guru mengajak anak ntuk menggosok gigi. Setelah itu guru mempersilahkan anak untuk beristirahat dan bermain bebas. Guru mengawasi kegiatan main anak dan kadang juga berpartisipasi bermain bersama anak.

Kegiatan inti dimulai dengan duduk melingkar, berdoa bersama, guru menjelaskan tema, kegiatan yang akan dilakukan setiap tempat main anak. Guru menyebut aktivitas anak dengan sebutan "bermain" dan menyebut anak dengan sebutan "teman". Guru menjelaskan alat dan bahan setiap kegiatan main anak. Guru menyediakan minimal tiga kegiatan main anak di setiap sentra. Guru mengawasi kegiatan main anak, membantu anak, memotivasi anak dengan sebutan "aku pasti bisa", setelah kegiatan main kurang dari 5 menit guru mengajak anak beres-beres dengan bernyanyi. Setelah selesai anak merapikan, guru mengajak anak untuk duduk melingkar kembali. Guru melakukan recalling, tentang aktivitas yang baru saja dilakukan, memberikan motivasi, dan pesan-pesan kemudian berdoa dan memanggil nama anak satu persatu untuk pulang.

\section{Penilaian pembelajaran}

Penilaian dilakukan sejak anak datang sampai anak pulang. Setiap guru membawa kertas kecil sehingga setelah pulang sekolah guru dapat mencatatkan nya dilembar penilaian. Jenis penilaian yang digunakan adalah penilaian catatan anekdot, penilaian hasil karya, penialaian unjuk kerja, penialaian percakapan, penugasan, penilaian portofolio dan observasi. Penilaian kegiatan pembelajaran anak dilakukan setiap hari yang mencakup indikator pembelajaran, kemudian di rekap dalam bentuk mingguan dan bulanan yang digunakan sebagai dasar untuk pelaporan kepada orang tua. Pelaporan berupa deskripsi pertumbuhan fisik dan perkembangan kompetensi sikap, pengetahuan, dan keterampilan anak yang dilaporkan kepada orang tua lengkap dengan lampiran hasil portofolio. Pelaporan dilakukan secara tertulis minimal enam bulan sekali sedangkan pelaporan secara lisan dapat dilakukan sesuai kebutuhan.

\section{Pembahasan}

Perencanaan pembelajaran dilaksanakan sesuai dengan dengan kurikulum yang telah di buat. Pembuatan perencanaan dilakukan jauh sebelum kegiatan pembelajaran sehingga saat pembelajaran guru sudah siap. Perencanaan TK yang meliputi promes (Program semester), RPPM (Rencana pelaksanaan pembelajaran mingguan), dan $\mathrm{RPPH}$ (Rencana pelaksanaan pembelajaran harian) harus siap, sehingga pembelajaran dapat berlangsung dengan baik. Walaupun dalam RPPH tidak dibuat perencanaan dengan sebutan pijakan namun aktifitas yang terlaksana tetap mengandung pijakan yang termasuk prinsip dalam pembelajaran sentra. Hal ini sesuai dengan pendapat Latif, dkk (2013) [6] yang meyatakan bahwa perencanaan dapat di tulis dengan format yang berbeda. Namun tetap mengandung prinsip perencanaan pembelajaran TK Pelaksanaan pembelajaran di TK Islam Bakti IX walaupun berbeda 
dengan penerapan sentra pada ummnya namun dalam kegiatan pembelajarannya tetap menerapkan prinsip pembelajaran sentra adanya pijakan didalamnya, yaitu pijakan awal, pijakan sebelum main, pijakan saat main, dan pijakan setelah main anak. Penataan lingkungan main anak dilakukan di awal, bisa di sebut dengan pijakan awal.

Hal ini sesuai dengan pendapat Depdiknas (2006) [5] menjelaskan bahwa penataan lingkungan main anak disebut dengan pijakan awal dan terdapat tiga pijakan dalam kegiatan inti yaitu pijakan pengalaman sebelum main (15 menit), pijakan pengalaman selama main (60 menit), dan pijakan pengalaman setelah main (30 menit). Sehingga kegiatan anak tetap mengandung pijakan yang akan membantu anak untuk mengoptimalkan perkembangannya sehingga anak dapat berkembang menuju kemampuan yang selanjutnya.

Penyambutan yang dilakukan saat anak datang dengan menanyakan kabar anak akan berguna untuk mengkondisikan anak untuk siap belajar di sekolah. Hal ini sesuai dengan pendapat Mulyasa (2017) [15] bahwa kegiatan penyambutan dapat berfungsi bagi guru untuk menetralisir kesedihan anak dengan melakukan kegiatan transisi seperti bermain dan, cerita dan puzzle. Sehingga kemampuan guru untuk mengetahui dan merasa perasaan anak dan memberikan timbal balik yang sesuai dapat berdampak positif bagi kegiatan anak selama satu hari di sekolah.

Pembiasaan NAM anak yang meliputi sholat dhuha, kegiatan berdoa dan menghafal sebagai bukti implementasi visi misi sekolah yang menginternalisasi nilai islam dalam kegiatan pembelajaran. Kemampuan anak usia dini yang masih berada pada tahap menirukan kegiatan beribada menjadikan guru harus mempimpin kegiatan sholat. Walaupun demikian kegiatan sholat juga kadang di pimpin oleh Kelompok B ketika sholat di lakukan secara bersama.

Beberapa kegiatan di TK Islam Bakti IX di lakukan sesuai kelompok usia namun kadang juga guru menyatukan aktivitas kegiatan menjadi kegiatan bersama. Sehingga anak yang berada di kelompok A dapat bersosialisasi dengan kelompok B. Beberapa kegiatan yang kadang dilakuan bersama adalah kegiatan senam fisik motorik, ektra tari, kegiatan sholat, makan bersama, kegiatan main di sentra keterampilan hidup. Seperti pada saat kegiatan membuat laba-laba dari roti oreo dan stik roti maka kelompok A dan kelompok B digabung menjadi satu.

Kebiasaan bersama dalam beberapa kegiatan menjadikan anak kelompok A memiliki keberanian untuk bersosialisasi dengan siappun, mengembangkan keberanian anak, mengembangkan kemampuan berbahasa anak karena adanya sosialisasi yang dan penambahan kosa kata dari luar diri anak. Sehingga saat waktu istirahat ditemui anak kelompok A dapat bermain dengan anak kelompok B.

Kegiatan inti di setiap sentra di lakukan dengan memberikan pijakan awal sesuai dnegan jenis sentra dan tema pembelajaran. kegiatan sentra bermain peran dilakukan dengan melibatkan anak aktif dalam kegiatan bermain dan menaati peraturan, menurut Bodrova (2008) menjelaskan bahwa hubungan yang inheren antara peran anak dalam kegiatan bermain dengan ketaatan pada aturan yang ada akan berpengaruh pada pengaturan diri anak Sehingga dengan kesadaran anak dengan adanya mitra dalam bermain dan juga aturan bermain diharapkan dapat menjadikan anak memahami dan menerapkan dalam kehidupannya. Selain itu guru selalu memberikan 
pijakan awal dalam setiap aktivitas anak, hal ini akan menunjang kemampuan anak dalamliterasi. Griffin, et al (2015) [17] berpendapat bahwa narasi wacana akan berpengaruh pada kemampuan literasi anak yaitu membaca dan menulis. Sehingga pentignya pererapan pijakan awal pada pembelajaran sentra untuk mengoptimalkan perkembangan anak.

Guru melakukan pijakan individu pada setiap anak. Aktifitas ini dilakukan dengan berkeliling saat kegiatan dilakukan dan membantu anak untuk menuju tahap kemampuan selanjutnya. Guru akan memotivasi anak ketika anak menyatakan dirinya tidak bisa, dengan mengucapkan kalimat "Aku pasti bisa", kemudian jika anak belum bisa dan tidak sesuai perintah maka guru akan memberikan contoh, namun jika anak sudah bisa bermain sendiri maka guru hanya mengamati dan memotivasi anak untuk menjadi lebih baik. Sehingga pemberian pijakan di TK pada setiap anak dilakukan dengan menyesuaikan pada tahap perkembangan anak.

Hal ini sesuai dengan pendapat Smith \& Dziurgot (2010) [18] bahwa pemberian pijakan dari orang dewasa kepada anak harus menyesuaikan dengan tingkat kebutuhan bermain anak. Pemberian pijakan lebih banyak pada anak yang butuh banyak bantuan dan semakin berkurang bahkan tidak diberikan pada anak yang sudah mampu bermain sendiri. Sehingga guru perlu untuk berhenti sejenak ketika ada anak yang meminta bantuan guru, Guru juga harus memahami tingkat kebutuhan bermain anak.

Hasil aktivitas main anak kemudian di dokumentasikan oleh guru setalah aktifitas bermain atau setelah semua anak pulang. Hal ini sesuai dengan pendapat Latif et al (2013) [6] yang menjelaskan bahwa pijakan individu dilakukan dengan guru memberikan kesempatan dan waktu agar anak memperluas pengalaman, guru mencontohkan komunikasi yang tepat dan efektif, memberi kesempatan anak untuk bersosialisasi dengan melalui dukungan bermain dengan teman sebaya, guru mendokumentasikan semua bentuk perkembangan dan kemajuan main anak dalam bentuk foto atau portofolio. Hanafi (2014) [3] menjelaskan bahwa pemberian kesempatan oleh guru untuk anak dalam memilih aktivitas main anak akan memberikan pengalaman yang bervarisi bagi anak.

Kegiatan membereskan mainan menjadi kebiasaan yang telah dilakukan anak. Anak setelah menggunakan mainan, setelah makan, setelah sholat merapikan dan mengembalikan sesuai tempatnya. Kegiatan merapikan yang dilakukan mengajarkan anak untuk bertanggung jawab dan terbiasa untuk mencintai kerapian dan teratur setelah berkegtan. Hal ini sesuai dengan pendapat Hanafi (2014) [3] yang menjelaskan bahwa kegiatan beres-beres mengajarkan anak bertanggung jawab, anak belajar klasifikasi, urutan dan penataan lingkungan secara tepat guna, sehingga hal ini menjadi hal yang mengesankan bagi anak, selain itu tugas guru adalah meluruskan pemahaman anak yang masih keliru.

Kegiatan makan bersama dilakukan dengan pembiasaan mencuci tangan, berdoa bersama, dan menggosok gigi setelah makan. Namun aktivitas menggosok gigi setelah makan hanya dilakukan ketika anak ingin dan guru tidak mewajibkan bahwa setelah makan harus menggosok gigi, padahal jika kebiasaan ini di jalankan dengan konsisten akan menjadi kebiasaan yang baik bagi anak. Caughlin, et al (1997) [19] berpendapat bahwa anak menggosok gigi setelah makan itu akan menjadi kebiasaan baik setiap hari, setiap anak memiliki sendiri sikat gigi dan setiap sikat gigi di beri 
nama sesuai nama anak. TK juga telah menerapkan untuk memberikan tempat khusus dan pemberian nama anak di sikat giginya. sehingga anak bisa menggunakan tanpa bingung mencarinya serta bisa belajar tentang pengenalan huruf.

Kegiatan penutup anak dilakukan dengan melakukan recalling, dan juga menanyakan perasaan anak. pemberian pengulangan bermanfaat bagus untuk memori jangka panjang anak (Desmita, 2013) [20]. maka diperlukannya pengulangan agar anak mengingat materi. Selain itu guru juga menjelaskan tentang aktivitas yang akan dilakukan besuk. Hal ini sejalan dengan pendapat Parkhurst (Sujiono, 2009) [21] pendidik menyampaikan rencana untuk besok. Selain itu guru juga mengajak anak berdoa bersama, dan mengatur pulang anak dengan memanggil nama anak dari satu-satu. Hal ini mengajarkan anak untuk mengenal nama diri, berdisiplin dan taat pada aturan yang telah disepakat bersama.

Penilaian pembelajaran pada TK yang menerapkan model pembelajaran sentra dilakukan meliputi evaluasi program dan evaluasi kemajuan perkembangan peserta didik (Depdiknas, 2006) [5]. Aktivitas penilaian di TK Islam Bakti IX sesuai dengan teori hal ini dikarenakan kepala sekolah secara kontinue melakukan evaluasi pada guru terkait pelaksanaan pembalajaran yang diterapkan dan melakukan masukanmasuka. Kemudian penilaian perkembangan anak yang meliputi enam aspek perkembangan anak dilakukan oleh semua guru setiap hari. Penilaian setiap hari kemudian di rekap menjadi penilaian mingguan dan penilaian bulanan yang akan menjadi dasar dalam penilaiaan yang akan di laporkan kepada orang tua. Hal ini sesuiai dengan teori dari Campbell dan Ruptic (Asmawati, 2014) [22] menjelaskan bahwa dalam proses pelaporan perkembangan anak di susun melalui proses analisis sintesis yaitu dengan mengumpulkan data hasil asesmen, kemudian interpretasi dari karakteristik anak, dan mengkomunikasikan hasil penilaian kepada orang tua tentang perkembangan anak.

Kegiatan pembelajaran sentra dilakukan secara moving class atau anak akan berpindah-pindah menyesuaikan dengan jadwal jenis sentra yang telah di tentukan. Beberapa sentra seperti sentra keterampilan hidup, sentra balok, sentra seni, dan sentra persiapan dilakukan secara moving class. Hal ini sesuai dengan pendapat Hanafi (2014) [3] bahwa kegiatan sentra dilakukan secara moving class. Namun untuk kegiatan sentra bermain peran maka kegiatan dilakukan di kelas masing-masing dan alat yang berpindah-pindah. Maka jenis perpindahan yang dilakukan di TK ini memiliki variasi.

\section{SIMPULAN}

Berdasarkan paparan hasil penelitian dapat diambil kesimpulan bahwa TK telah menerapkan sesuai dengan teori pelaksanaan model pembelejaran sentra. Pembelajaran sentra dilakukan dengan persiapan pelaksanaan yaitu penyiapan pendidik, penyiapan tempat dan alat, dan memberikan sosialisasi kepada orang tua di awal tahun ajaran baru. Penerapan model pembelajaran sentra meliputi perencanaan, pelaksanaan dan evaluasi. Perencanaan pembelajaran TK Islam Bakti IX Surakarta menggunakan kurikulum 2013 yang dikembangkan sesuai kebutuhan TK. Sehingga TK menerapkan kurikulum tingkat satuan pendidikan anak usia dini (KTSP PAUD).

TK menerapkan lima jenis sentra yaitu sentra balok, sentra keterampilan hidup, sentra seni, sentra persiapan, dan sentra bermain peran. 
Kegiatan berlangsung sejak jam 07.3011.30 WIB. Setiap hari diterapkan satu jenis sentra. Anak melakukan perpindahan tempat namun untuk sentra bermain peran justru peralatan yang dipindah. Penilaian di TK Islam Bakti IX Surakarta menggunakan teknik pengamatan, percakapan, penugasan, unjuk kerja, penilaian hasil karya, pencatatan anekdot, dan portofolio. Hasil penilaian dirangkum dalam rentang waktu harian, mingguan, atau bulanan. Kesimpulan penilaian mingguan atau bulanan sebagai dasar laporan perkembangan anak kepada orang tua.

\section{DAFTAR PUSTAKA}

[1] Suyadi. (2014). Teori pembelajaran anak usia dini dalam kajian neurosains. Bandung: PT Remaja Rosdakarya.

[2] Aziz, A. (2017). Implementasi inovasi pada model-model pendidikan anak usia dini di Taman Pengasuhan Anak (TPA) Serama Kementerian Kesehatan RI. Jurnal Pendidikan Usia Dini, 11 (2), 201214.

http://journal.unj.ac.id/unj/index.p hp/jpud/article/view/4893

Diperoleh pada 20 Maret 2018.

[3] Hanafi, Z. (2014). Implementasi metode sentra dalam pengembangan kecerdasan majemuk anak usia dini TK Batitus Al-Ilmi Bekasi. Yogyakarta: Deepublish.

[4] Oktaria, R. (2014). Evaluasi program implementasi pendekatan Beyond Centers and Circle Time (BCCT). Jurnal Pendidikan Usia Dini. Universitas Negeri Jakarta, 8 (2) 337-352.

https://media.neliti.com/media/pub lications. Diperoleh pada 20 Maret 2018.
[5] Departemen Pendidikan Nasional. (2006). Pedoman penerapan pendekatan "Beyond Centers and Circle Time (BCCT)" (Pendekatan Sentra dan Lingkaran) dalam Pendidikan Anak Usia Dini. Jakarta: Direktorat Jenderal Pendidikan Luar Sekolah Direktorat Pendidikan Anak Usia Dini.

[6] Latif, et al. (2013). Orientasi pendidikan anak usia dini, teori dan aplikasi. Jakarta: kencana Prenada Media Group.

[7] Suyadi \& Dahlia. (2014). Implementasi dan inovasi kurikulum PAUD 2013, program pembelajaran berbasis multiple intelligences. Bandung: PT Remaja Rosdakarya.

[8] Claesses, A \& Garrett, R. (2014). The role of early childhood settings for 4-5 year old children in early academic skills and later achievement in Australia. Early Childhood Research Quarterly. 29: 550501.

https://doi.org/10.1016/j.ecresq. 2014.06.006. Diperoleh pada 12 Maret 2018.

[9] Lestari, Y., Marhaeni, A A I N., \& Suastra, W. (2013). Penerapan model pembelajaran Beyond Centers and Circle Time (BCCT) untuk meningkatkan minat dan aktivitas belajar anak kelompok B TK Bumi Gora BPKBM NTB. E-journal Program Pascasarjana Universitas Pendidikan Ganesha Program Studi Pendidikan Dasar, 3. http://download.portalgaruda.or g/article.php. Diperoleh pada 14 maret 2018 . 
[10] Masrurah, F. (2014). Kecerdasan verbal-linguistik anak melalui pendekatan Beyond Centers and Circle Time (BCCT). Jurnal Lisan Al-Hal, 6(2), 305-334. http://ejournal.kopertais4.or.id/tapa lkuda/index.php/lisan/article/view/ 1192. Diperoleh pada 20 Maret 2018.

[11] Hurlock, E. B. (2013). Perkembangan anak. Jakarta : Erlangga.

[12] Wiyani, N. A. (2014). Psikologi perkembangan anak usia dini panduan orang tua dan pendidik PAUD dalam memahami serta mendidik anak usia dini. Yogyakarta: Penerbit Gava Meida.

[13] Allen, K. E \& Marotz, L. R. (2010). Profil perkembangan anak prakelahiran hingga usia 12 tahun (Terj. Valentino). Jakarta: PT Indeks.

[14] Beaty, J. J. (2013). Observasi perkembangan anak usia dini (Terj. Arif Rakhman). Jakarta: Kencana Prenadamedia Group.

[15] Mulyasa, H. E. (2017). Strategi pembelajaran PAUD. Bandung: PT Remaja Rosdakarya.

[16] Bodrova, E. (2008). Make-believe play versus academic skills: a Vygotskian approach to today's dilemma of early childhood education. Europan Early Childhood Education Research Journal, 16 (3): 357-369. https://doi.org/10.1080/135029308 02291777. Diperoleh pada 10 Oktober 2018.

[17] Griffin, T.M., et al. (2015). Oral discourse in the preschool years and later literacy skills. First
Language. 24 (2): 123-147. https://doi.org/10.1177/0142723 704042369. Diperoleh pada 20 Maret 2018.

[18] Smith, J.T \& Dziurgot, T. (2010). 'Good-fit' teacher-child play interactions and the subsequent autonomous play of preschool children. Early Childhood Reseach Quartely. 26: 110-123. https://doi.org/10.1016/j.ecresq. 2010.04.005. Diperoleh pada 12 Oktober 2018.

[19] Caughlin, et al. (1997). Creating child-centered classrooms: 3-5 years old. New York: Children's Resources International.

[20] Desmita. (2013). Psikologi perkembangan. Bandung: PT Remaja Rosdakarya.

[21] Sujiono, Y. N. (2009). Konsep dasar pendidikan anak usia dini. Jakarta: PT Indeks.

[22] Asmawati, L, dkk. (2008). Pengelolaan kegiatan pengembangan anak usia dini. Jakarta: Universitas Terbuka. 